\title{
Role of Glycine Betaine and Potassium Nitrate in Drought Tolerance using Proline Accumulation in Rice (Oryza sativa L.)
}

\author{
Nitish Sharma ${ }^{1}$, A.K. Singh ${ }^{1}$, Nikita Nehal ${ }^{1 *}$, Krishna Kumar Mishra ${ }^{2}$ \\ and Mayanker Singh ${ }^{1}$ \\ ${ }^{1}$ Department of Crop Physiology, ${ }^{2}$ Department of Post-Harvest Technology, NDUA\&T, \\ Kumarganj, Faizabad-224229, India
}

*Corresponding author

\section{A B S T R A C T}

Present investigation was carried out in the rainout shelter at Student Instructional Farm (SIF), Narendra Deva University of Agriculture and Technology, Kumarganj, Faizabad (U.P.) during Kharif (wet season) 2015 and 2016. Experiments were laid out in

\section{Keywords}

Rice, Biochemical,

Yield, Drought, Glycine betaine and potassium nitrate

Article Info

Accepted:

20 June 2018

Available Online:

10 July 2018 randomized block design with 3 replications, one variety i.e. Swarna Sub land nine foliar treatments. Rice plants were exposed to drought at 60 DAT for 15 days by holding irrigation during drought treatment. During drought treatment soil moisture tension of the field was ranged from $60-80 \mathrm{kPa}$. Foliar application of different concentrations of glycine betaine (100 and $200 \mathrm{ppm})$ applied at 60 DAT and different concentrations of $\mathrm{KNO}_{3}(2$ and $3 \%$ ) applied at 30 DAT and at 60 DAT as well as their combination increased chlorophyll, proline content in leaves. Increased proline accumulation with foliar treatments during drought provides resistance against reactive oxygen species and protected the quaternary structure of proteins thus prevented oxidative damage to membranes and enhanced Antioxidative defense system under osmotic stress and ultimately produces higher test weight as compared to control with distilled water treatment and exposed to drought. However, among all the treatments, $\mathrm{T}_{7}$ (foliar spray of glycine betaine@ 200 ppm at 60 DAT) showed maximum chlorophyll content while maximum proline content and test weight found in $\mathrm{T}_{9}$ (foliar spray of $\mathrm{KNO}_{3} @ 2 \%$ at 30 DAT and glycine betaine @ 200 ppm at 60 DAT ) during both the years. Thus, it may be concluded that combination of $\mathrm{KNO}_{3} @ 2 \%$ applied at 30 DAT and glycine betaine @ 200 ppm applied at 60 DAT can be used to improve test weight under drought at flowering stage in rice by enhancing proline accumulation.

\section{Introduction}

Rice (Oryza sativa L.) is a major staple food crop in many parts of the world, feeding more than three billion people and providing 50-80 $\%$ of their daily calories intake (Khush, 2005). It is a drought susceptible crop exhibiting serious deleterious effects when exposed to water stress at critical growth stages especially at reproductive stage (Suriyan et al., 2010). Drought is one of the major abiotic stresses that's everely affect and reduce the yield and productivity offood crops worldwide up to 70\% (Kaur et al., 2008; Thakur et al., 2010; 
Akram et al., 2013). The response of plants to drought stress is complex and involves changes in their morphology, physiology and metabolism. Reduction of plant growth is the most typical symptom of drought stress (Sairam and Srivastava, 2001).

Increased production of compatible solutes (known as osmolytes) in response to drought stress is generally observed in a variety of plants. These compatible solutes are highly soluble organic compounds, with nontoxic nature at higher concentration and carry no net charge at physiological $\mathrm{pH}$. Further, these are accumulated in form of betaines, polyols, oligosaccharides, aminoacids etc. in higher plants. Glycinebetaine (GB) is one such osmolyte whose association with tolerance to abiotic stresses has been supported by a number of publications (Manaf, 2016; Wang et al., 2010; Park et al.,2007).The researches on manipulation of GB biosynthetic pathway by genetic transformation and exogenous application are in continuous progress. However, exogenousfoliar application of GB represents a short and simple approach for mitigating the adverse effects of stress.

According to IPIOUAT-IPNI Intern Symposium (2009) mineral-nutrient status of plants has major role in its adaptation to stress. $\mathrm{K}$ plays a vital role in improving the plant resistance. Kregularizes physiological processes like photosynthesis, translocation of cations into sink organs, regulation of turgor pressure and enzymes activation (Mengel andKirkby, 2001). During stress condition, ROS formation was induced andoxidative damage to cells occurred and requirement for $\mathrm{K}$ was increased (Foyer et al., 2002). This enhanced need for $\mathrm{K}$ by plants suffering from drought stress showed that $\mathrm{K}$ is required for photosynthetic and $\mathrm{CO}_{2}$ fixation, because water deficit caused stomatal closure and decreased the $\mathrm{CO}_{2}$ fixation. Mengel and Kirkby (2001) observed that due to low K concentration, ROS production was induced during water deficit which caused disturbance in stomatal opening. Low grain yield resulting from water deficit could be overcome by increasing $\mathrm{K}$ supply (Damon and Rengel, 2007). Results reviewed in this section indicate that under water limited conditions, yield losses can be minimized by the sufficient supply of K.

\section{Materials and Methods}

The present investigation was carried out in the rainout shelter $(25 \mathrm{~m}$ length and $7.5 \mathrm{~m}$ width) of the Student Instructional Farm (SIF), Narendra Deva University of Agriculture and Technology, Kumarganj, Faizabad (U.P.) during Kharif (wet season) 2015 and 2016. Experiments were laid out in randomized block design with three replication and one variety i.e. Swarna Sub 1. Twenty five days old seedlings were transplanted in the rainout shelter. At 60 DAT plants were exposed to drought by holding irrigation for 15 days and rainout shelter was properly covered with the polythene to avoid the rainwater during the drought treatment. During 15 days of drought treatment soil moisture tension was measured and it was ranged from $60-80 \mathrm{kPa}$, after 15 days of drought treatment field was reirrigated to release drought. The treatments comprised of $\mathrm{T}_{1}$ (Control- Distilled water spray), $\mathrm{T}_{2}$ (foliar spray of $\mathrm{KNO}_{3} @ 2 \%$ at $30 \mathrm{DAT}$ ), $\mathrm{T}_{3}$ (foliar spray of $\mathrm{KNO}_{3} @ 3 \%$ at $30 \mathrm{DAT}$ ), $\mathrm{T}_{4}$ (foliar spray of $\mathrm{KNO}_{3} @ 2 \%$ at $60 \mathrm{DAT}$ ), $\mathrm{T}_{5}$ (foliar spray of $\mathrm{KNO}_{3} @ 3 \%$ at $60 \mathrm{DAT}$ ), $\mathrm{T}_{6}$ (foliar spray of glycine betaine @ 100 ppm at $60 \mathrm{DAT}$ ), $\mathrm{T}_{7}$ (foliar spray of glycine betaine @ 200 ppm at 60 DAT), $\mathrm{T}_{8}$ (foliar spray of $\mathrm{KNO}_{3}$ @ 2\% at 30 DAT and glycine betaine @ 100 ppm at 60 DAT) and $\mathrm{T}_{9}$ (foliar spray of $\mathrm{KNO}_{3}$ @ 2\% at 30 DAT and glycine betaine @ 200 ppm at 60 DAT).Chlorophyll and proline were recorded at before and after drought and test weight was recorded after harvesting. Chlorophyll content of leaf was directly 
measured in intact leaves with the help of microprocessor based plant efficiency analyzer model: X55/M-PEA. Third leaf from the top was taken for this purpose. Free proline content in leaves was estimated spectro-photometrically according to the methods of Bates et al., (1973).1000-grains were counted from the samples of each treatment. These counted grains were weighed and recorded as test weight at $15 \%$ moisture level.

\section{Results and Discussion}

Data pertaining to chlorophyll content in leaf, influenced by foliar spray of different concentrations of glycine betaine and $\mathrm{KNO}_{3}$ (Osmoprotectants) alone as well as their combination applied at different stages on rice plants exposed to drought stress at flowering stage (60 DAT) recorded at different growth stages have been presented in Table 1. At 60 days after transplanting (before drought treatment), among all the treatments significant increase in chlorophyll content was recorded in $T_{3}$ followed by $T_{2}, T_{8}$ and $T_{9}$ in year 2015-16 while rest of the treatments viz., $\mathrm{T}_{4}, \mathrm{~T}_{5}, \mathrm{~T}_{6}$ and $\mathrm{T}_{7}$ showed non-significant effect over $\mathrm{T}_{1}$. Likewise in year 2016-17, $\mathrm{T}_{3}$ registered significant increase in chlorophyll content followed by $T_{9}, T_{2}$ and $T_{8}$ while rest of the treatments viz., $\mathrm{T}_{4}, \mathrm{~T}_{5}, \mathrm{~T}_{6}$ and $\mathrm{T}_{7}$ showed non-significant effect over $\mathrm{T}_{1}$. At termination of drought (i.e. at 75 days after transplanting) show significant increase in chlorophyll content during both the years. However in year 2015-16 among the treatments, maximum chlorophyll content was recorded in $\mathrm{T}_{7}$ followed by $\mathrm{T}_{8}, \mathrm{~T}_{6}, \mathrm{~T}_{4}$ and $\mathrm{T}_{2}$ while minimum was noted in $T_{1}$. Similarly in year 2016-17, maximum chlorophyll content was recorded in $\mathrm{T}_{7}$ followed by $\mathrm{T}_{8}, \mathrm{~T}_{9}, \mathrm{~T}_{5}, \mathrm{~T}_{3}, \mathrm{~T}_{6}, \mathrm{~T}_{4}$ and $\mathrm{T}_{2}$ while minimum was noted in $\mathrm{T}_{1}$.Chlorophyll is one of the major components to determine the yield as it is a photosynthetic pigment and helps in the net photosynthesis process. Under drought stress reduction in chlorophyll content is common. In the present study, the effect of drought stress on chlorophyll content is mitigated with the foliar application of glycine betaine and potassium nitrate. The result indicates that foliar spray of glycine betaine and $\mathrm{KNO}_{3}$ maintained higher chlorophyll content under drought, might be because of the role of solute in protecting the photosynthetic machinery from oxidative damage Cha-um et al., (2013). Similar results were also found by Shallan et al., (2012)who reported that exogenous application of solutes like glycine betaine, putrescine etc. ameliorate the negative effect of drought by preventing photosynthetic machinery.

Data regarding proline content, influenced by the foliar spray of different concentrations of glycine betaine and $\mathrm{KNO}_{3}$ (Osmoprotectants) alone as well as their combination applied at different stages on rice plants exposed to drought stress at flowering stage (60 DAT) recorded at different growth stages have been presented in Table 2. Data obtained at 60 days after transplanting (before drought treatment) showed that among all the treatments, maximum proline content was recorded in $\mathrm{T}_{3}$ followed by $\mathrm{T}_{9}, \mathrm{~T}_{8}, \mathrm{~T}_{2}$ while rest of the treatments viz., $\mathrm{T}_{4}, \mathrm{~T}_{5}, \mathrm{~T}_{6}, \mathrm{~T}_{7}$ showed nonsignificant effect over $\mathrm{T}_{1}$ in year 2015-16 and 2016-17 respectively. Moreover, proline content recorded at termination of drought (i.e. at 75 days after transplanting) showed that all the treatments significantly increased the proline content during both the years (2015-16 and 2016-17). However in both the year among the treatments, maximum proline content was recorded in $\mathrm{T}_{9}$ followed by $\mathrm{T}_{8}, \mathrm{~T}_{7}$, $\mathrm{T}_{5}, \mathrm{~T}_{3}, \mathrm{~T}_{6}, \mathrm{~T}_{4}, \mathrm{~T}_{2}$ and while minimum was noted in $\mathrm{T}_{1}$. Similarly in year 2016-17 among the treatments, maximum proline content was recorded in $\mathrm{T}_{9}$ followed by $\mathrm{T}_{8}, \mathrm{~T}_{7}, \mathrm{~T}_{5}, \mathrm{~T}_{3}, \mathrm{~T}_{6}$, $\mathrm{T}_{2}$ and $\mathrm{T}_{4}$ while minimum was noted in $\mathrm{T}_{1}$. Proline has been assigned the role of cyst solute, a storage compound or a protective agent for cytoplasmic enzymes and cellular 
structure (Pandey and Ganapathy, 1985). Hanson and Hits (1982) suggested that proline accumulation is a consequence of stress induced damage to cells. In plants, the role of proline may not be restricted to that of compatible osmolytes, but proline synthesized during water deficit and salt stress may serve as an organic nitrogen reserve that can be utilized during recovery (Trotel et al.,
1989).These results are in agreement with the findings of Farooq et al., (2008), Anjum et al., (2012) and Zhang et al., (2013) who reported that exogenous application of glycine betaine and potassium increased the proline content which can be utilized during recovery and thereby helps to reduce damage to plant cells and to maintain membrane integrity.

Table.1 Effect of foliar spray of glycine betaine and $\mathrm{KNO}_{3}$ on chlorophyll content (SPAD Value) in leaves of rice plants exposed to $60-80 \mathrm{kPa}$ drought stress at $60 \mathrm{DAT}$

\begin{tabular}{|c|c|c|c|c|c|c|}
\hline \multirow{2}{*}{\multicolumn{3}{|c|}{$\begin{array}{l}\text { Stage } \rightarrow \\
\text { Treatments } \\
\downarrow \text { Year } \rightarrow\end{array}$}} & \multicolumn{2}{|c|}{60 DAT } & \multicolumn{2}{|c|}{75 DAT } \\
\hline & & & \multirow{2}{*}{$\begin{array}{c}\text { 2015-16 } \\
12.31\end{array}$} & \multirow{2}{*}{$\begin{array}{c}\text { 2016-17 } \\
13.47\end{array}$} & \multirow{2}{*}{$\begin{array}{r}\mathbf{2 0 1 5}-16 \\
10.22\end{array}$} & \multirow{2}{*}{$\begin{array}{r}\text { 2016-17 } \\
11.20\end{array}$} \\
\hline $\mathrm{T}_{1}$ & $:$ & Untreated & & & & \\
\hline $\mathrm{T}_{2}$ & $:$ & Foliar spray of $\mathrm{KNO}_{3} @ 2 \%$ at 30 DAT & 14.44 & 15.27 & 11.17 & 12.09 \\
\hline$T_{3}$ & : & Foliar spray of $\mathrm{KNO}_{3} @ 3 \%$ at $30 \mathrm{DAT}$ & 15.17 & 15.91 & 11.74 & 12.65 \\
\hline $\mathrm{T}_{4}$ & : & Foliar spray of $\mathrm{KNO}_{3} @ 2 \%$ at 60 DAT & 12.77 & 13.09 & 11.30 & 12.27 \\
\hline$T_{5}$ & : & Foliar spray of $\mathrm{KNO}_{3} @ 3 \%$ at $60 \mathrm{DAT}$ & 12.34 & 13.71 & 12.09 & 12.71 \\
\hline $\mathrm{T}_{6}$ & : & $\begin{array}{l}\text { Foliar spray of glycine betaine @ } 100 \\
\text { ppm at } 60 \text { DAT }\end{array}$ & 11.97 & 12.99 & 11.87 & 12.64 \\
\hline $\mathrm{T}_{7}$ & : & $\begin{array}{l}\text { Foliar spray of glycine betaine @ } 200 \\
\text { ppm at } 60 \text { DAT }\end{array}$ & 12.78 & 13.09 & 13.65 & 14.02 \\
\hline $\mathrm{T}_{8}$ & : & $\begin{array}{l}\text { Foliar spray of } \mathrm{KNO}_{3} @ 2 \% \text { at } 30 \text { DAT } \\
\text { and glycine betaine @ } 100 \mathrm{ppm} \text { at } 60 \\
\text { DAT }\end{array}$ & 14.11 & 15.07 & 12.82 & 13.27 \\
\hline $\mathrm{T}_{9}$ & : & $\begin{array}{l}\text { Foliar spray of } \mathrm{KNO}_{3} @ 2 \% \text { at } 30 \text { DAT } \\
\text { and glycine betaine @ } 200 \mathrm{ppm} \text { at } 60 \\
\text { DAT }\end{array}$ & 13.92 & 15.57 & 12.74 & 12.96 \\
\hline \multicolumn{3}{|c|}{ SEm \pm} & 0.26 & 0.31 & 0.26 & 0.28 \\
\hline \multicolumn{3}{|c|}{$\mathrm{CD}$ at $5 \%$} & 0.79 & 0.94 & 0.79 & 0.84 \\
\hline
\end{tabular}


Table.2 Effect of foliar spray of glycine betaine and $\mathrm{KNO}_{3}$ on proline content $\left(\mu \mathrm{g} \mathrm{g}^{-1}\right.$ fresh weight) in leaves of rice plants exposed to $60-80 \mathrm{kPa}$ drought stress at $60 \mathrm{DAT}$

\begin{tabular}{|c|c|c|c|c|c|c|}
\hline \multirow{2}{*}{\multicolumn{3}{|c|}{$\begin{array}{l}\text { Stage } \rightarrow \\
\text { Treatments }\end{array}$}} & \multicolumn{2}{|l|}{$60 \mathrm{DAT}$} & \multicolumn{2}{|l|}{$75 \mathrm{DAT}$} \\
\hline & & & $2015-16$ & 2016-17 & $2015-16$ & 2016-17 \\
\hline $\mathrm{T}_{1}$ & : & Untreated & 341.69 & 356.77 & 449.83 & 468.50 \\
\hline $\mathrm{T}_{2}$ & : & Foliar spray of $\mathrm{KNO}_{3} @ 2 \%$ at $30 \mathrm{DAT}$ & 385.67 & 404.74 & 490.56 & 514.10 \\
\hline $\mathrm{T}_{3}$ & : & Foliar spray of $\mathrm{KNO}_{3} @ 3 \%$ at $30 \mathrm{DAT}$ & 412.05 & 428.38 & 544.95 & 551.44 \\
\hline $\mathrm{T}_{4}$ & : & Foliar spray of $\mathrm{KNO}_{3} @ 2 \%$ at $60 \mathrm{DAT}$ & 347.98 & 360.33 & 491.40 & 504.71 \\
\hline $\mathrm{T}_{5}$ & : & Foliar spray of $\mathrm{KNO}_{3} @ 3 \%$ at $60 \mathrm{DAT}$ & 345.46 & 354.26 & 547.79 & 559.07 \\
\hline $\mathrm{T}_{6}$ & : & $\begin{array}{l}\text { Foliar spray of glycine betaine @ } 100 \text { ppm } \\
\text { at } 60 \text { DAT }\end{array}$ & 349.23 & 347.98 & 523.73 & 540.64 \\
\hline $\mathrm{T}_{7}$ & : & $\begin{array}{l}\text { Foliar spray of glycine betaine @ } 200 \text { ppm } \\
\text { at } 60 \text { DAT }\end{array}$ & 356.77 & 356.77 & 551.11 & 577.80 \\
\hline $\mathrm{T}_{8}$ & : & $\begin{array}{l}\text { Foliar spray of } \mathrm{KNO}_{3} @ 2 \% \text { at } 30 \mathrm{DAT} \\
\text { and glycine betaine @ } 100 \mathrm{ppm} \text { at } 60 \mathrm{DAT}\end{array}$ & 388.18 & 409.53 & 561.42 & 582.21 \\
\hline $\mathrm{T}_{9}$ & : & $\begin{array}{l}\text { Foliar spray of } \mathrm{KNO}_{3} @ 2 \% \text { at } 30 \text { DAT } \\
\text { and glycine betaine @ } 200 \mathrm{ppm} \text { at } 60 \text { DAT }\end{array}$ & 392.05 & 414.66 & 592.34 & 621.70 \\
\hline \multicolumn{3}{|c|}{ SEm \pm} & 7.30 & 7.83 & 11.43 & 11.90 \\
\hline \multicolumn{3}{|c|}{$\mathrm{CD}$ at $5 \%$} & 21.89 & 23.46 & 34.25 & 35.69 \\
\hline
\end{tabular}

Table.3 Effect of foliar spray of glycine betaine and $\mathrm{KNO}_{3}$ on test weight $(\mathrm{g})$ of rice plants exposed to $60-80 \mathrm{kPa}$ drought stress at $60 \mathrm{DAT}$

\begin{tabular}{|c|c|c|c|c|}
\hline \multirow{2}{*}{\multicolumn{3}{|c|}{$\begin{array}{l}\text { Treatments } \\
\downarrow\end{array}$}} & \multicolumn{2}{|c|}{ Test weight (g) } \\
\hline & & & $2015-16$ & 2016-17 \\
\hline \multicolumn{5}{|c|}{ 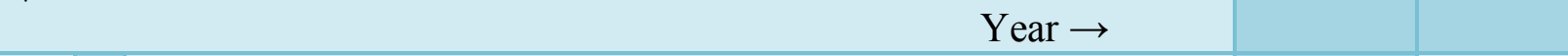 } \\
\hline $\mathrm{T}_{1}$ & : & Untreated & 15.80 & 16.37 \\
\hline $\mathrm{T}_{2}$ & : & Foliar spray of $\mathrm{KNO}_{3} @ 2 \%$ at $30 \mathrm{DAT}$ & 17.11 & 17.91 \\
\hline $\mathrm{T}_{3}$ & : & Foliar spray of $\mathrm{KNO}_{3} @ 3 \%$ at $30 \mathrm{DAT}$ & 17.32 & 18.24 \\
\hline $\mathrm{T}_{4}$ & : & Foliar spray of $\mathrm{KNO}_{3} @ 2 \%$ at $60 \mathrm{DAT}$ & 17.57 & 18.39 \\
\hline $\mathrm{T}_{5}$ & : & Foliar spray of $\mathrm{KNO}_{3} @ 3 \%$ at $60 \mathrm{DAT}$ & 17.89 & 18.84 \\
\hline $\mathrm{T}_{6}$ & : & Foliar spray of glycine betaine @ 100 ppm at 60 DAT & 18.12 & 19.09 \\
\hline $\mathrm{T}_{7}$ & : & Foliar spray of glycine betaine @ 200 ppm at 60 DAT & 18.97 & 19.47 \\
\hline $\mathrm{T}_{8}$ & : & $\begin{array}{l}\text { Foliar spray of } \mathrm{KNO}_{3} @ 2 \% \text { at } 30 \mathrm{DAT} \text { and glycine betaine @ } \\
100 \text { ppm at } 60 \mathrm{DAT}\end{array}$ & 19.54 & 19.94 \\
\hline $\mathrm{T}_{9}$ & : & $\begin{array}{l}\text { Foliar spray of } \mathrm{KNO}_{3} @ 2 \% \text { at } 30 \text { DAT and glycine betaine @ } \\
200 \text { ppm at } 60 \text { DAT }\end{array}$ & 19.82 & 20.22 \\
\hline \multicolumn{3}{|c|}{$\mathrm{SEm} \pm$} & 0.40 & 0.41 \\
\hline \multicolumn{3}{|c|}{$\mathrm{CD}$ at $5 \%$} & 1.19 & 1.22 \\
\hline
\end{tabular}


It is clear from the data presented in Table 3 that all the foliar spray of different concentrations of glycine betaine and $\mathrm{KNO}_{3}$ (Osmoprotectants) alone as well as their combination applied at different stages on rice plants exposed to drought stress at flowering stage (60 DAT) significantly increased the test weight under drought stress.Data reveal that all the treatments significantly increased test weight under flowering stage drought during both the years (2015-16 and 2016-17). However among the treatments, maximum test weight i.e. 19.82 and $20.22 \mathrm{~g}$ was recorded in $\mathrm{T}_{9}$ followed by $\mathrm{T}_{8}, \mathrm{~T}_{7}, \mathrm{~T}_{6}, \mathrm{~T}_{5}, \mathrm{~T}_{4}$, $\mathrm{T}_{3}, \mathrm{~T}_{2}$ while minimum test weight was found in $\mathrm{T}_{1}$ in year 2015-16 and 2016-17 respectively. Glycine betaine and potassium nitrate treatment might have improved yield performance of rice under drought stress possibly by better net photosynthetic assimilation (Gupta and Thind, 2015; Kausar et al., 2014).

\section{References}

Akram, H.M., Ali, A., Sattar, A., Rehman, H.S.U. and Bibi, A. (2013). Impact of water deficit stress on various physiological and agronomic traits of three Basmati rice (Oryza sativa L) cultivars. J. Anim. Plant Sci.23(5): 14151423.

Anjum, S.A., Saleem, M.F., Wang, L.C., Bilal, M.F. and Saeed, A. (2012).Protective role of glycinebetaine in maize against drought-induced lipid peroxidation by enhancing capacity of antioxidantive system. Aust J Crop Sci., 4: 576-583.

Bates, L.S., Waldren, R.P. and Teere, V. (1973).Rapid determinations of free proline for water stress studies. Plant and Soil, 39: 205-207.

Cha-um, S., Samphumphuang, T. and Kirdmanee, C. (2013). Glycinebetaine alleviates water deficit stress in Indica rice using proline accumulation, photosynthetic efficiencies, growth performances and yield attributes. Aust. J. Crop Sci., 7(2): 213-218.

Damon, P. M. and Rengel, Z. (2007). Wheat genotypes differ in potassium efficiency under glasshouse and field conditions. Aust J Agric Res. 58: 816-823.

Farooq M., Basra, S.M.A., Wahid, A., Cheema, Z.A., Cheema, M.A. and Khaliq, A. (2008). Physiological role of exogenously applied glycine betaine to improve drought tolerance in fine grain aromatic rice (Oryza sativa L.).J. Agron. Crop Sci., 194: 325-333.

Foyer, C.H., Vanacker, H., Gomez, L.D. and Harbinson, J. (2002). Regulation of photosynthesis and antioxidant metabolism in maize leaves at optimal and chilling temperatures: review. Plant PhysiolBiochem.40: 659-668.

Gupta, N. and Thind, S.K. (2015).Improving photosynthetic performance of bread wheat under field drought stress by foliar applied glycine betaine. $J$ AgricSci Technol., 17: 75-86.

Hanson, A.D. and Hits, E.D. (1982). Metabolic responses of mesophytes to plant water deficits. Annu Rev Plant Physiol., 33: 163-203.

IPI-OUAT-IPNI Intern Symposium (2009). Potassium. In: Brar MS (ed) Role and benefits in improving nutrient management for food production, quality and reduced environ-mental damage. Symposium proceedings, Orissa University of Agriculture and Technology, Bhubaneswar, India, 5.- 7. November 2009, Intern. Potash Institute, Horgen, Switzerland, inpress.

Kaur, G., Kumar, S., Nayyar, H. and Upadhyaya, H.D. (2008). Cold stress injury during the pod-filling phase in chickpea (Cicer arietinumL.): effects on quantitative and qualitative components of seeds. J. Agron. Crop Sci.194(6): 457- 
464.

Kausar, N., Nawaz., K., Hussain., K., Bhatti., K.H., Siddiqi., E.H. and Tallat. A. (2014). Effect of exogenous applications of glycine betaine on growth and gaseous exchange attributes of two maize (Zea mays L.) cultivars under saline conditions. World Appl. Sci. J., 29(12): 1559-1565.

Khush, G.S. (2005). What it will take to feed 5.0 billion rice consumers in 2030. Plant Mol. Biol., 59: 1-6.

Manaf, H.H. (2016). Beneficial effects of exogenous selenium, glycine betaine and seaweed extract on salt stressed cowpea plant. Ann Agric Sci. 61: 41-48.

Mengel K. and Kirkby, E.A. (2001).Principles of PlantNutrition.5th ed., Kluwer Academic Publishers, Dordrecht.

Pandey, R. and Ganapathy, P.S. (1985).The proline enigma $\mathrm{NaCl}$ Cicer arientinum. Plant Science, 40: 1.3-1.7.

Park, E.J., Jeknic., Z., Pino., M.T., Murata. N. and Chen. T.H.H (2007). Glycine betaine accumulation is more effective inchloroplasts than in the cytosol for protecting transgenic tomato plants against abiotic stress. Plant Cell Environ.30: 994-1005.

Sairam, R.K. and Srivastava, G.C. (2001). Water stress tolerance of wheat (Triticum aestivum L.): variations in hydrogen peroxide accumulation and antioxidant activity in tolerant and susceptible genotypes. J. Agron. Crop Sci. 186:63-70.

Shallan, Magdy A., Hassan, Hazem M.M.,
Namich, Alia A.M. and Ibrahim, Alshaimaa A. (2012). Effect of sodium nitroprusside, putrescine and glycine betaine on alleviation of drought stress in cotton plant. American-Eurasian J. Agric. Environ. Sci., 12(9): 1252-1265.

Suriyan, C., Yamgwech, S.Y. and K. Supaibulneatana, K. (2010).Water deficit stress in the productive stage of four indica rice (Oryza sativa L.) genotypes. Pakistan J. Bat., 42(5). 3387-3398.

Thakur, P., Kumar, S., Malik, J.A., Berger, J.D. and Nayyar, H. (2010). Cold stress effects on reproductive development in grain crops: an over view. Environ. Exp. Bot. 67(3): 429-443.

Trotel, P., Bouchercu, A., Niograt, M.F. and Laher, F. (1989). Effect of osmo accmulated proline in leaf discs of rape (Brassica napu L.) incubated in a medium of low osmomorlity. Pl. Sci.,118: 31-45.

Wang, G.P., Zhang., X.Y., Li., F., Luo. Y. and Wang.W. (2010). Over accumulation of glycine betaine enhances toleranceto drought and heat stress in wheat leaves in the protection of photosynthesis. Photosynthetica.48: 117-126.

Zhang, L., Gao, M., Zhang, L., Li, B., Han, M., Alva, A.K. and Ashraf, M. (2013). Role of exogenous glycine betaine and humic acid in mitigating drought stressinduced adverse effects in Malusrobusta seedlings. Turk J. Bot., 37: 920-929.

\section{How to cite this article:}

Nitish Sharma, A.K. Singh, Nikita Nehal, Krishna Kumar Mishra and Mayanker Singh. 2018. Role of Glycine Betaine and Potassium Nitrate in Drought Tolerance using Proline Accumulation in Rice (Oryza sativa L.). Int.J.Curr.Microbiol.App.Sci. 7(07): 2916-2922. doi: https://doi.org/10.20546/ijcmas.2018.707.341 